The great contributions of the "Horologium Oscillatorium" may be summarized as the introduction of work and energy considerations in the solution of the problem of the centre of oscillation, the proof that the cycloid is the tautochrone, the study of evolutes and the theorems on centrifugal force. One might go so far as to say that Huygens recognized implicitly all the laws which Newton made explicit in dynamics: the work on centrifugal force required a grasp of the second law, the compound pendulum illustrated the third law applied in a difficult example. Not until the time of D'Alembert, remarked Whewell ${ }^{3}$, was the representation of the laws of motion in their most general form fully achieved. Huygens, Mariotte, the brothers Bernoulli, de l'Hôpital and Brook Taylor all took a part in the history of this advance, but of them all Huygens made the greatest inductive contribution.

\footnotetext{
I There is a German translation: "Ostwald's Klassiker der Exakten Wissenschaften", No. 192, and one in French: "Guvres Complètes de Christiaan Huygens", 18, published by the Société Hollandaise des Sciences (1934).

2 “(Euvres Complètes”, 18, 635.

3 "History of the Inductive Sciences", 2, 59 and Chap. v.
}

\title{
THE AMERICAN ASSOCIATION FOR THE ADVANCEMENT OF SCIENCE
}

\author{
By DR. F. R. Moulton, Permanent Secretary
}

\section{Durham (New Hampshire) MeEting}

$\mathrm{S}^{\mathrm{T}}$ INCE 1931 the American Association for the Advancement of Science has held two meetings each year, the annual meeting during the Christmas holiday week and a summer meeting, usually in June. The large annual meetings are held in cities able to provide accommodation for several thousand men of science and about sixty rooms for holding scientific sessions. The summer meetings are usually held in smaller cities offering exceptional attractions. In June 1938, the Association met in Ottawa, Canada. This year it held its meeting in Durham, New Hampshire, during June 23-27, in connexion with the celebration of the seventy-fifth anniversary of the founding of the University of New Hampshire. It will strike British readers as curious that the seventy-fifth anniversary of the founding of a university should be the occasion for a celebration. However, in September the Association will participate in the symposia organized by the University of Chicago in celebration of its fiftieth anniversary.

In certain respects the Durham meeting resembled some of the meetings of the British Association. It was held at a university in a small town surrounded by a delightful countryside. The sea was near by in one direction, and lakes and mountains in the other. Summer was at its loveliest and the vacation period was at hand. There was an air of leisureliness that is unusual in American meetings. There was music, and there were social functions and many tours and excursions.

Stated statistically, about a thousand persons attended the meeting and fifty-one sessions were held at which two addresses were delivered and two hundred and ten papers were presented. In addition, there were several round-table discussions, eleven special luncheons and dinners at most of which addresses were delivered, five demonstrations and exhibits, and thirty-four tours and excursions for scientific purposes. Several of these excursions were continued well beyond the period of the meeting. In fact, the botanists continued their excursion through the State of Maine for a week after the meeting closed.

For several years the section on social and economic sciences has taken for the general theme of its programmes for the summer meetings the racial origins and social and economic patterns of the various peoples of the regions in which the meetings are held. Since New Hampshire is one of the New England States, the present inhabitants of New England were the subject of the programme of the section. The Pilgrims landed at Plymouth Rock in 1620 and for nearly two hundred years most of the immigrants to this region came from England. During this interval an orderly, cultured and somewhat aristocratic society developed. Then, with the rapid development of manufacturing and because of difficult conditions in Europe, wave after wave of new immigrants poured into New England - the Irish, the Italians, the FrenchCanadians and smaller percentages from every country from the Atlantic Ocean to the Ural Mountains. Twenty-seven papers were devoted to discussions of the human, religious, political, social and economic problems that were raised by these mass transfers of populations, and by the sudden and complete change in their occupations and living conditions.

Perhaps the most thoroughly organized and 
completely carried out programme was the symposium by the entomological societies on "Laboratory Procedures in Studies of the Chemical Control of Insects". The programme, which was presented at four sessions extending through two days, consisted of eleven principal topics which were formally discussed by invited leaders and informally discussed by other experts in the respective fields. It is expected that the Association will publish this symposium in the near future.

It would be erroneous and futile to pretend that the men of science who were gathered at Durham thought only of the niceties of mathematical theories, of the meteorology of New England, of the complex origin and formation of its mountains, of its fauna and flora, of the qualities and functioning of the human mind, of the complexities of society, of the progress in the medical sciences, and in agriculture and forestry. All these were considered, and although they were considered seriously they only caught the conscious attention and held it temporarily. Deep reverberations of a new Blitzkrieg were coming out of Russia, "nearer, clearer, deadlier than before!" Civilization was, and is, making history around a sharp curve, and freedom was, and is, being defended principally by the gallant people of one small island. In the presence of such a tide in the affairs of men the attention could not long be held fixed exclusively by the wavelets of small additions to scientific knowledge.

Yet science gives a perspective that is unique. It deals with great distances, long periods of time, tremendous forces. It sees in outline the evolution of life from amœba to man. Against the background of the struggle of all life for existence it looks on the tragic vicissitudes of human history. It finds in the lower animals the elementary characters that in more complex combinations determine the nature of man. It gathers wisdom from all the history of the world instead of from only its last illegible page. It has no early millennium to offer, but it can point out certain pathways that should be avoided and others that are promising. And this men of science of the American Association, as well as those of the British Association, regard as one of their responsibilities to society.

\section{O B I T UAR IES}

\section{Prof. J. C. Philip, O.B.E., F.R.S.}

$\mathbf{J}^{\mathrm{A}}$ MES CHARLES PHILIP, born at Fordoun, Kincardineshire, on February 12, 1873, was both a son and nephew of the manse. He went to Aberdeen Grammar School and afterwards to the University, where in 1895 he was Murray scholar. He was a pupil of Japp and probably went to Göttingen on the latter's suggestion to become acquainted with the new science of physical chemistry as taught by Nernst.

In 1897 he came to work under H. E. Armstrong at the Central Technical College in South Kensington. Armstrong, though very critical of the doctrines of Ostwald and Nernst, was anxious to know of them at first hand. Less than a year later he was able to place Philip at Cambridge with Heycock and Neville, then engaged on their classic work on the constitution of binary alloys, in the interpretation of which the phase rule was to prove so helpful.

Philip stayed at Cambridge for a while but seized the first opportunity to return to London to the Royal College of Science as demonstrator and lecturer in January 1900. Here he remained all his life, becoming assistant professor in 1909 and first professor of physical chemistry in 1913. This was one of the earliest chairs in this subject in Great Britain. When Prof. H. B. Baker retired in 1932 he was made director of the Laboratories of Inorganic and Physical Chemistry. He took part in the design of the new laboratories in Imperial Institute Road begun in 1906 and busied himself more and more in every form of college activity - both official and social. He served for six years, 1932-38, on the Sonate of the University, and was dean of the Faculty of Science in 1934 and deputy vice-chancellor during 1937-38.

Besides his teaching, Philip was actively engaged in research largely in collaboration with a continuous succession of students. His investigations ranged over a wide field: the properties of non-aqueous solutions (especially of electrolytes in organic solvents); adsorption of dissolved substances and vapours on charcoal ; determination of the dielectric constant of liquids; molecular refraction ; freezingpoint diagrams of binary systems; chemical fogs.

It is particularly to his credit that he left behind him a strong school of younger men who to-day make the Imperial College a prominent centre of physical chemical training and research. It was characteristic of him to encourage his younger men to follow their own varied bents, and he shared his research students among them.

$\mathrm{He}$ became a fellow of the Royal Society in 1921. An honour which pleased him greatly was the honorary degree of LL.D. from his old. University, Aberdeen, conferred on him in July of this year.

During the War of 1914-18 he was secretary of the Royal Society War Committee and largely concerned with organizing the preparation of local anæsthetics in university laboratories. In recognition of this work he was awarded the O.B.E. 